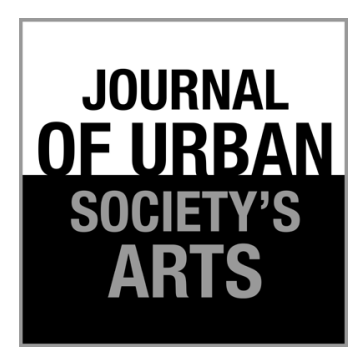

Volume 8 Number 1 , April 2021: 36-48

\section{Selling Spectacular Urban Life: Urban Space and Lifestyle in the Promotion Media of Apartment in Yogyakarta}

\author{
Ratna Noviani and Elok Santi Jesica \\ Media and Cultural Studies Program, The Graduate School \\ Gadjah Mada University \\ Jl. Teknika Utara, Pogung, Yogyakarta 55281 \\ Email: ratna.noviani@ugm.ac.id; HP.: +62 81227407660
}

\begin{abstract}
This article discusses how urban life is represented through the Barsa City, Uttara the Icon, and The Palace apartment advertisements and promotional videos. Applying Guy Debord's idea of spectacle to examine how urban life is transformed into visualization and commodification, also George Ritzer's idea of re-enchantment of the disenchanted world and the new means of consumption, this article is aimed to analyze the position of apartments in the urban space of Yogyakarta that is discursively constructed through apartment promotional media. The conclusion of this research shows that apartments are functionalized to create the spectacle of the city. Urban space and life are aestheticized and spectacularized, in which apartments are displayed as part of dramatic and extravagant urban arts. Presented as one-stop-serving buildings, the apartments also promote the fusion of living space, urban style experience, and consumption, which lead to the difficulty in distinguishing spatial boundaries. The advertisements and promotional videos of the apartment in Yogyakarta also promote temporal paradox. On the one hand, it promotes time compression and speed, on the other hand it promotes prolonged and extended time to foster consumption in the urban space.
\end{abstract}

Keywords: apartment; advertisement; urbanspace; lifestyle; spectacle

\begin{abstract}
ABSTRAK
Menjual Kehidupan Perkotaan yang Spektakuler: Ruang Perkotaan dan Gaya Hidup dalam Media Promosi Apartemen di Yogyakarta. Artikel ini membahas tentang bagaimana kehidupan urban direpresentasikan melalui iklan dan video promosi apartemen Barsa City, Uttara the Icon, dan The Palace. Penelitian ini menerapkan ide spectacle dari Guy Debord untuk mengkaji bagaimana kehidupan urban ditransformasikan menjadi visualisasi dan komodifikasi, juga ide George Ritzer terhadap "pesona kembali pada dunia muram" dan "sarana konsumsi baru". Artikel ini bertujuan untuk menganalisis posisi apartemen di perkotaan. ruang kota di Yogyakarta yang dikonstruksi secara diskursif melalui media promosi apartemen. Kesimpulan dari penelitian ini menunjukkan bahwa apartemen difungsikan untuk menciptakan sebuah tontonan kota. Ruang dan kehidupan kota menjadi suatu hal yang diestetiskan dan dispektakularisasikan, yaitu di mana apartemen ditampilkan sebagai bagian dari seni urban yang dramatis dan boros. Disajikan sebagai bangunan satu atap, apartemen ini juga mempromosikan perpaduan ruang hidup, pengalaman gaya perkotaan, dan konsumsi, yang menyebabkan kesulitan dalam membedakan batas spasial. Iklan dan video promosi apartemen di Yogyakarta juga mempromosikan paradoks temporal. Di satu sisi, mempromosikan kompresi waktu dan kecepatan, di sisi lain mempromosikannya dalam waktu yang lama dan diperpanjang untuk mendorong daya konsumsi di ruang perkotaan.
\end{abstract}

Kata kunci: apartemen; iklan; ruang kota; gaya hidup; tontonan 


\section{Introduction}

As a historical city, Yogyakarta is always interesting to talk about. Not to mention, its status as a student city makes Yogyakarta an attractive destination that is well worth visiting. Yogyakarta is also known as the second popular tourist destination in Indonesia after the city of god, Bali. In the last decade, Yogyakarta has even been considered as a region for profitable investment. It could be seen from the growing development projects of housing and industrial property in the region, including landed and vertical housing. One of the vertical housing projects aimed at the urban middle class in Yogyakarta is the apartment project. The high demand for apartments in Yogyakarta in 2018 has made developers shift their focus to meeting the need for apartments rather than landed houses (Bank Indonesia, 2019: 56). Data from Rumah. com Property Index in 2017 (Askia, 2017) shows that the sales of apartment units in the Special Region of Yogyakarta, especially in the city of Yogyakarta and Sleman district, is relatively high. It is not surprising that the number of apartment development projects in the city of Yogyakarta and Sleman district continues to increase from year to year. In 2019 alone, five new apartments were built in Sleman. Until 2015, the Regional Government of Sleman Regency did not issue a regulation aiming to control the growth of hotel and apartment development projects in the district. On the contrary, based on Regulation of Mayor Yogyakarta No. 77/ 2013, there was an imposition of moratorium on new building permit (IMB) applications for hotels and apartments in the city of Yogyakarta. The moratorium was valid until the end of 2016. As a result, property developers shifted their development projects from Yogyakarta city to Sleman district. However, in 2015 a moratorium on building permit applications for hotels, apartments, and condotels was also imposed in Sleman based on Regent Regulation No. 63/2015. The moratorium is valid until 31 December 2021. With the construction permit obtained before the moratorium, until 2021 there will be 17 apartments available and operate in Sleman district (radarjogja. jawapos.com, 2019).
It is important to note that the mushrooming of apartment buildings in the Special Region of Yogyakarta is, to some extent, related to the city branding of Yogyakarta as a student city. Apart from Gadjah Mada University (UGM) as one of the oldest universities in Indonesia, there are many other big universities, both public and private, that are located in Yogyakarta. Every year, these universities accept thousands of new students from all over Indonesia, even from overseas. These newly enrolled students definitely need an accommodation to stay and live during their studies in Yogyakarta. They become a niche market to target in the apartment business. It is unsurprising that the new apartment projects mostly locate not far from big campuses in Yogyakarta. The closeness to campuses become a pivotal point which is claimed and highlighted in advertisement and other promotional media of such apartments. As an example, in its promotional video, Uttara the Icon apartment marks out its location within walking distance from UGM. Similarly, The Palace apartment which is located in the northern side of Yogyakarta uses the word "close" in its advertisements to indicate the spatial distance between the apartment and several campuses in Yogyakarta including UGM and Indonesian Islamic University (UII). Barsa City's apartment shows the same tendency in its advertisement. It does not overtly mention spatial distance to certain campuses, but mentioning "study" in its advertisement indicates that students are part of its target market. Interestingly, albeit targetting students as the target market, advertisement and promotional video of apartments in Yogyakarta do not specifically depict and promote student life. Instead, it mostly represents Yogyakarta and its urban life. Departing from the fact, this article is aimed to examine how the position of apartment in the urban space of Yogyakarta is discursively constructed in the promotional media. It begins with the assumption that in such promotional media, Yogyakarta as a cultural as well as student city is depicted as a spectacular city within the discourse of consumerism and urban lifestyle. This article uses Guy Debord's idea of spectacle (1967/2002) to scrutinize how urban life is transformed into visual forms and commodified through apartments' 
promotional media. In addition, this paper also works with George Ritzer's (2010) idea of reenchantment of the disenchanted world and of new means of consumption. Ritzer's ideas are used to examine the aestheticization of urban space through spectacular new means of consumption named apartments.

Some researches on apartment projects in Yogyakarta have been previously conducted. Octasya Yusnindita Devi and W. Pradoto (2017) for example, conducted research entitled "The Existence of Apartments and Their Effects on Social and Economic Activities in the Seturan Area, Yogyakarta." Devi and Pradoto discussed the impact of Student Park and Student Castle apartments in Seturan area on the physical, social, and economic developments of the surrounding community. By using the survey method, both of them found that the existence of apartments in Seturan area had a significant social and economic impact on the people surrounding the apartments. The social impact that Devi and Pranoto underlined in their research was the increasing number of residents living in the apartments, which caused crowded and congested areas in Seturan. The economic impact was indicated by the increasing dynamic of trade activities and growing competitive investment. Added to that, Devi and Pranoto revealed that the existence of apartments has led to the soaring land prices of the area. However, in their research, Devi and Pranoto did not examine how developers of the apartment in Seturan constructed promotional discourse to attract consumers. Another study on apartment projects in Yogyakarta was conducted by Benedikta Thia (2014) entitled "Mapping of Students' Perception toward Apartment Positioning in Yogyakarta”. For her thesis research at the Catholic University of Atma Jaya Yogyakarta, Thia began with the assumption that seven apartments in Yogyakarta actually built similar positioning, namely, as a student apartment. Therefore, her study was aimed to reveal the mapping of perception among students at five universities in Yogyakarta toward positioning built by those apartments. The study showed that only one out of seven apartments, which had a different positioning. The other six apartments tended to compete very tightly and put themselves in the same position. Based on the mapping of students' perceptions of apartment positioning, Thia concluded that similar positioning was considered less profitable in terms of apartment marketing. In her study, Thia focused more on students as target consumers and ignored the discourse of urban life built by each apartment in its promotional media.

Regarding urban life, Kusrini (2016) examined how urban life is narrated visually in her work entitled "Street Photography: Framing a City in a Story." She analyzed photos of street photography by Erik Prasetya in the book "Jakarta: Estetika Banal" which is published by KPG \& Jakarta Arts Council 2011. She chose photographs of Jakarta from 1990-2000 as her main corpus to show how urban life in Jakarta was told through visual texts. Other than examining photographic techniques, Kusrini also looked at the various sides and dynamics of urban life captured in Erik Prasetya's photos. However, in her study, Kusrini did not explore the issue of lifestyle and consumer culture in urban life such as Jakarta. In their work entitled "The Visual Language of Consumerism in Contemporary Artworks", Singgih Prio Wicaksono \& Anik Juwariyah (2019) examined how the discourse of consumerism is presented through visual language. They focused on four popular contemporary artworks, namely, "Campbell's Soup Cans" by Andi Warhol, "Jesus Christ with Shopping Bags" by Banksy, "I Shop Therefore I Am" by Barbara Kruger, and Ron English's "Super Supper". In their study, Wicaksono and Juwariyah not only analyzed the visual techniques applied by the four artworks but also delineated how visual symbols and signs are functionalized to express consumerism and discourse of popular culture satirically and sarcastically. However, both of them did not analyze more detail the social criticism against consumerism and popular culture represented in the four contemporary artworks.

From the previous studies on apartment and urban life, it could be seen that apartment as an object of study, which is linked to the discourse of urban life and consumerism has not been explored. By applying multimodal critical discourse analysis from Gunther Kress and Theo van Leeuwen, this 
article is aimed to critically examine how the discourse of spectacular urban life is constructed in promotional media of apartments in Yogyakarta. According to Kress and van Leeuwen (Noviani, 2018: 112) multimodality underlines the use of more than one semiotic mode to produce meaning. Each semiotic mode such as image, writing, layout, music, sound, gesture, and so on has its own capacity to generate meaning. Those different semiotic modes form a multimodal ensemble, which works together to produce a certain meaning. By means of multimodal critical discourse analysis from Kress and van Leeuwen, this article attempts to show how multimodal ensembles used in the promotional media of apartments in Yogyakarta generate meaning of urban space and lifestyle. Promotional media of three apartments in Yogyakarta, namely, Barsa City, Uttara the Icon, and the Palace are chosen as the main corpus. This article focuses mainly on the advertisement and promotional video of those apartments. There are 3 advertisements of Barsa City (2019), Uttara the Icon (2014), and The Palace (2019). Different from Barsa City and the Palace, which release updated advertisements in 2019, Uttara the Icon only has the 2014 version of advertisement. This article also analyzes 3 promotional videos, namely, video of Barsa City (2017), Uttara the Icon (2014), and The Palace (2019). Barsa City is a mixed-use development project undertaken by the Ciputra Group. Apart from the apartment project, Barsa City also manages the development project of shopping gallery, shop-houses, co-working space, and hotel in the same area (kabarbisnis.com, 2017). As a mixed-use development project, Barsa City focuses not merely on constructing the buildings, but also on creating urban settlements in the area. The apartment of Barsa City has been actively being promoted and opened for sale since November 2017. The construction itself only began in early 2019. The apartment of Barsa City reached a high rate of sales with $71 \%$ units sold in February 2018 (jogja.tribunnews.com, 2018). Apartment of Uttara the Icon has been operating earlier than Barsa City apartment, to be specific since 2017. The construction of the apartment undertaken by P.T. Bukit Alam Permata began in 2014. In
2017, Uttara the Icon was awarded the Property Developer's Consumer Choice Awards 2017 as The Most Preferred Apartments in the cities of Yogyakarta, Solo, and Semarang (uttaratheicon. co.id, 2017). Meanwhile, the Palace apartment and condotel obtained a permit in 2014 but the construction only began in 2015 undertaken by PT Funaru Berkah. The apartment construction of Barsa City, Uttara the Icon, and the Palace equally faced social protests from the communities surrounding the projects with regard to license or permit issues. However, these issues will not be examined throughout this article.

\section{Spectacle of the City: Urban Life as Commodity}

In his seminal work "The Society of the Spectacle" Guy Debord (Debord, 1967/2002) asserts, "Urbanism -" city planning"-is capitalism's method for taking over the natural and human environment. Following its logical development toward total domination, capitalism now can and must refashion the totality of space into its own particular decor" (Theses 169, inner quotes in original). City as space and its inner life become parts of reflexive project of capitalism. Life under the control of capitalism, according to Debord, is presented as "an immense of accumulation of spectacles" (Theses 1). Everything that is alive in the present day is represented through various visual images. In Debord's view, the spectacle is not a collection of visual images; instead, it is "a social relation between people that is mediated by images" (Theses 4). In the society of the spectacle, all aspects of life transform into commodities. Life, accordingly, is filled with an abundance of images and commodities. Life aspects are now presented and mediated through various images and commodities, likewise with urban space and life. Cities, on this point, undergo spectacularization and turn into commodities that we both consume and live in. Steven Miles (2010: 132) in a similar tone, writes in his book "Space for Consumption" that cities are "what and where we consume". Cities, hence, are constantly refined and aestheticized to gain attention from the public as well as capital. 
In his book "Enchanting a Disenchanted World: Continuity and Change in the Cathedrals of Consumption", George Ritzer (2010: 118) argues that capitalist domination in the realm of consumption is marked by re-enchantment of the new means of consumption. Referring to Guy Debord's idea, Ritzer underscores that spectacle is presented in various forms of new means of consumption to win consumers' attention. Shopping malls, theme parks, luxury gated communities, and casino are a few examples of it. In his book, Ritzer does not mention apartments specifically. However, Ritzer's explanation of luxury gated communities fits the context of apartments. Luxury gated communities, in Ritzer's view (2010: 23) are new means of consumption that offer expensive and luxurious homes. More than that, luxury gated communities also provide fancy facilities and lavish lifestyle to the occupants. Urban apartments also use a similar line of thinking, a variety of luxurious and extravagant lifestyle are also promoted to win attention from prospective buyers or tenants. Spectacles in the form of new means of consumption are created through implosion, both temporal and spatial. Ritzer defines implosion as "the disintegration or disappearance of boundaries so that formerly differentiated entities collapse in on each other" (2010: 132).

The spatial implosion refers to the disappearing or blurring of the boundaries of spaces so that differences between spaces become effaced. The emergence of a mega-mall or superstore is a striking example of spatial implosion. In the past time, fashion boutiques, salons, and cafes were located in different places. In a mega-mall or superstore, all those facilities are brought together in one place. The separate entities of space are imploded blurring all the boundaries and distinctions between spaces. Added to that, space-time compression has been facilitated and accelerated by communication and transportation technology. Physical distance is easily overcome, so is temporal restriction. Shopping time, for example, is no longer restricted because more and more new means of consumption provide 24-hours service. In the digital era, shopping even can be done everywhere, anytime, with just onetouch on the screen. The spectacle, according to Ritzer, makes life even more enchanting and alluring to live.

The spectacle of the city also involves constant re-enchantment of urban space and life. The rise of city branding shows how cities are increasingly positioned as commodities to be displayed, promoted, and sold. In this case, the city with its life is visualized and defined in terms of consumerism. Not surprisingly, urban life is commodified and offered for sale through various commercial marketing campaigns. Visualization and imagery of the city involve not only physical spaces but also symbolic spaces as well as experiences of the city. Urban space and life are formed and displayed with tangible and intangible attributes. In this context, the role of advertising and mass media is important in generating meaning and images of spectacular urban space and life. Anne M. Cronin (2010: 3) asserts that advertising, especially outdoor advertising, does not merely characterize urban spatiality, but it also portrays urban space as a sign system. On the one hand, posters and billboards of outdoor advertising adorn and characterize urban spaces. On the other hand, advertising also depicts urban space and life in the form of signs. In other words, advertising shows a significant role in shaping urban visual culture. In his study of advertising, Sut Jhally (2009) adds that advertising constructs commercial discourses which, often become our references and lens to think, act and understand the world around us (in Cronin, 2010: 7). Concerning urban culture, advertising plays a significant role in constructing discourse of urban life, not only concerning physical spaces but also to the relationships between people and things.

\section{Aestheticizing Urban Space}

One most striking feature, which is directly seen in the advertisement of Barsa City, Uttara the Icon, and The Palace is the lavish tall building of apartment. The skyscraper building type turns out to be the highlighted icon. The under-studied advertisements show a similar pattern of design, which depicts a lavish tall building in modern architecture surrounded by greenery and green landscape with some people doing activities. The 
tall building appears to be a significant marker of conjoining modernity and traditional culture in the well-known cultural city of Yogyakarta. According to Stephen Graham (2016: 758), tall buildings or skyscrapers are frequently considered as markers of modernity and futurity in urbanism. It is unsurprising that promotions run by three apartments in Yogyakarta attempt to expose high-rise buildings as symbols of modernity and futurity. Barsa City even emphasizes this point by using written semiotic mode in the form of the tagline "the essence of modern lifestyle" in its promotional video. To highlight the marker of modernity, those apartments even remove images of other landed houses or buildings in the vicinity and replace them with an image of green landscape in its advertisements, as seen in Figure 1, 2, and 3. Putting together a high rise building and greenery or green landscape looks more prominent in the promotional video of The Palace, as seen in Figure 4. In its advertisement, The Palace also attempts to include the view of Mount Merapi as part of the mesmerizing natural view in the north of Yogyakarta. It seems that The Palace wants to emphasize the added value of living in the north side of Yogyakarta, where the advertised apartment locates.

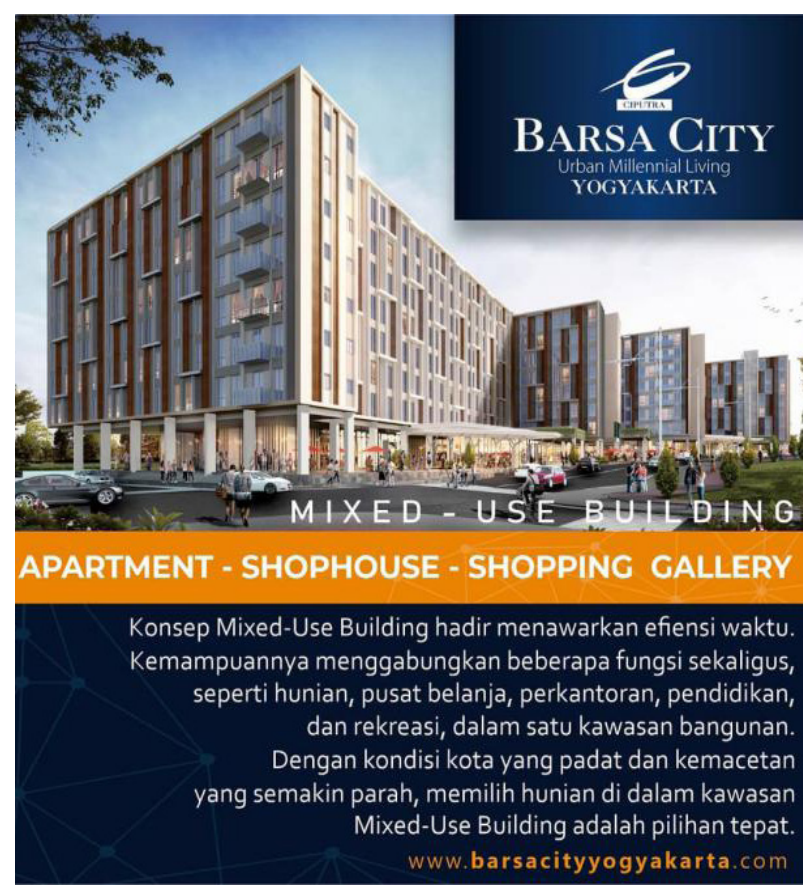

Figure 1. Advertisement of Barsa City. Source: https://www. facebook.com/BarsaCity/photos/a.1550954665028266/ 2252252804898445

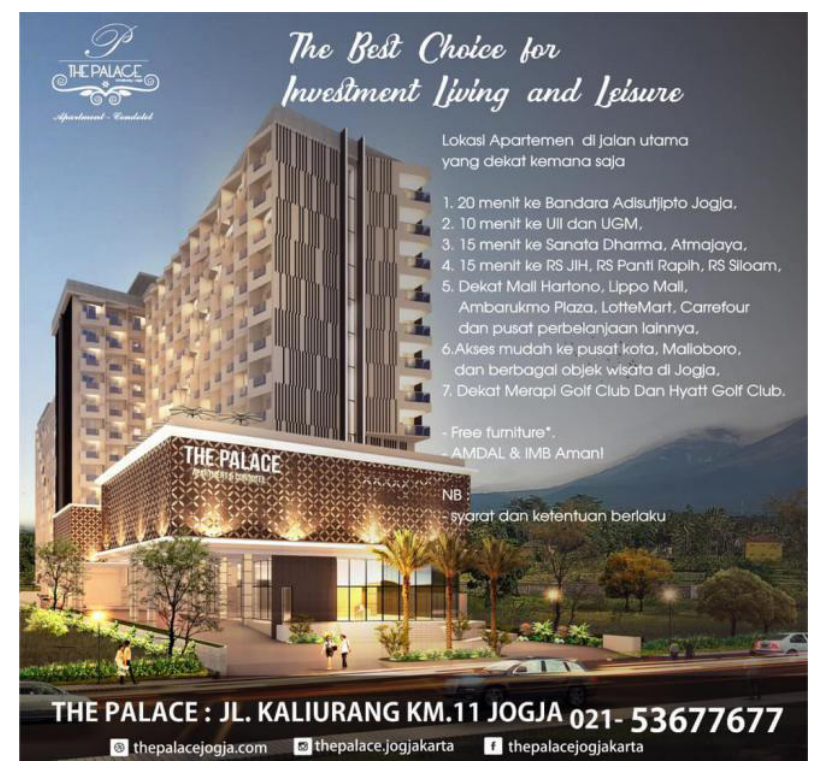

Figure 2. Advertisement of The Palace. Source: https://www. facebook.com/thepalacejogja/photos/a.50969690604 5759/1046665365682241

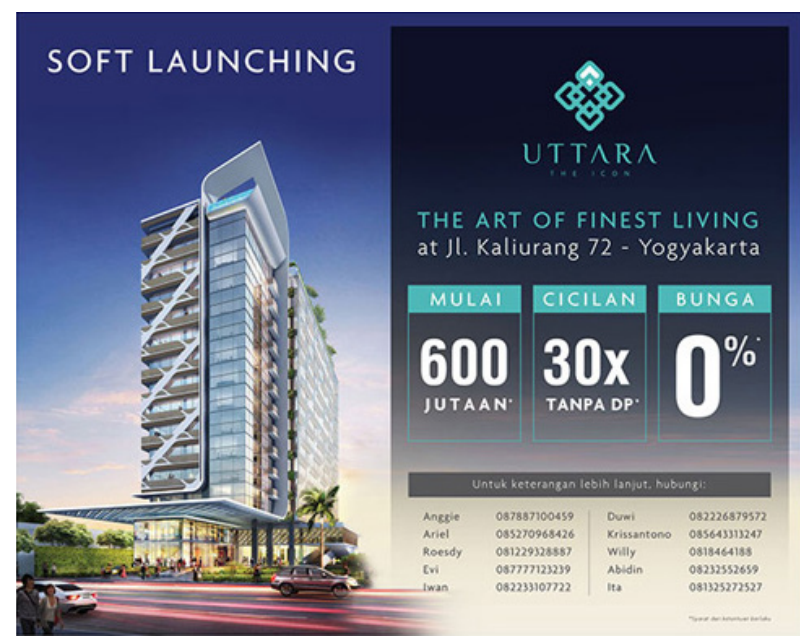

Figure 3. Advertisement of Uttara the Icon. Source: https:// www.uttaratheicon.co.id/news_4.html

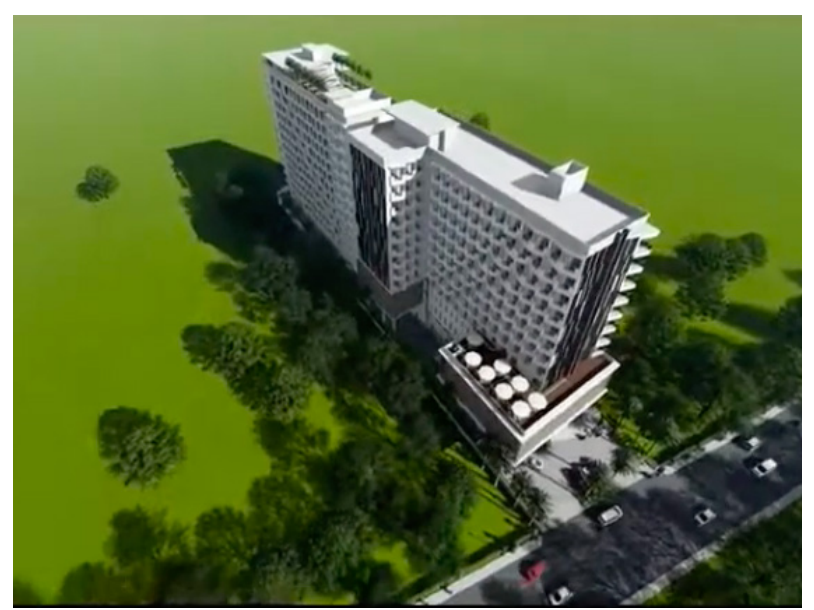

Figure 4. Green Landcape surrounding a High-Rise Building. Source: Promotional Animation Video of The Palace (Min. 00:02:02). https://www.youtube.com/watch? $\mathrm{v}=\mathrm{HLa9}$ s_pcC-w 
A similar strategy is applied by Uttara the Icon, which locates in the same street as The Palace. In contrast with The Palace, Uttara the Icon prefers to render the view of Mount Merapi in its promotional video to its advertisement. Not only does Uttara the Icon provide a great panoramic view of the Majestic Mount Merapi, but it also aims to offer a harmonious relationship with nature. It uses the on-screen text "in harmonious with nature" in its video, while rendering moving visual images of greenery surrounding the apartment. Incorporating the discourse of nature and images of greenery seems to be a distinct strategy applied by those apartments to avoid the notion that modernity causes ecological problems. It is a well-known fact that the construction of building in an urban area like apartments has led to the loss of green areas, the problem of clean water supply, and so on. To avoid this impression, those apartments provide an image of a green landscape and promote a harmonious life with nature. This spectacle of harmonious urban life with nature, obviously, seals the fact that most tall buildings anywhere in the world foster energy waste and require high operational cost (Ali \& AlKodmany, 2012: 385).

The tall buildings represented by the three apartments are also considered as part of the urban arts that creates such an aesthetic feeling. Aestheticization of urban space, on this point, is undertaken by using the tall buildings, whose inner and outer sides have already been aestheticized. Such an aestheticization is aimed to create a spectacle of urbanized fabric of everyday in the consumer society. As asserted by Mike Featherstone (2007: 66), the aestheticization of urbanized daily life is a "constant reworking of desires through images" which is part of the ruling economic order. Such desires are continuously evaluated, updated, embodied, and circulated in the form of commodities. The aestheticization of everyday life, in Featherstone's view, is also a process of transforming everyday life as a work of arts. Not surprisingly, tall buildings have been considered and positioned as part of urban arts that decorate urban space. It is in line with Guy Debord's idea (1967/2002, theses 169) that urban space will continue to be polished and made beautiful as part of the decor of the capitalist system. Aestheticization of apartment is clearly visible in the under-studied advertisements and promotional videos. The visual images of tall buildings with its architectural beauty, the light that shining from the inside out, the shining glass of apartment windows are elements, which are accentuated to gain attention from viewers. Spatial layout and the light colors are also functionalized in the advertisements as well as promotional videos to generate a dramatic and extravagant display of apartments. In his article "Why the Skyscraper?", Jean Gottmann (1966: 210) suggests that the color of the lights that comes out from the tall buildings such as apartments is part of an effort to build the art of urban living. Added to that, large glass windows and lights from inside the apartment allow people outside of the building to access urban inner life. The art of living in urban space, on this point, is marked by the sparkling colorful lights that come out of the tall buildings.

Meanwhile, the architectural details, both in the inner and outer parts of the building, also function to aestheticize the apartments. Putting together modernity and traditionality seems to be a distinct strategy in creating an apartment as a spectacle. Yogyakarta as a city of culture is positioned as the source of inspiration to furnish and decorate the inner and outer parts of the building. It is seen particularly in advertisements and promotional videos of The Palace and Uttara the Icon. The Palace, for example, shows how their architectural ornaments are inspired by batik, as part of the traditional arts of Yogyakarta. It uses Kawung, one of the oldest Javanese batik motifs, as the inspiration for its outer and inner architectural building ornaments. Similarly, Uttara the Icon in its promotional video explains that their architectural building ornaments are mostly inspired by batik Parang, also one of the oldest Javanese batik motifs. Building aestheticization of Uttara the Icon involves not merely batik, but also other artworks that are existed in old buildings in Yogyakarta or created by people from Yogyakarta. Uttara the Icon also emphasizes the aestheticized inner parts of the apartment, from the lobby to the apartment rooms. Various works of art from sculptures to paintings are also rendered in its video, being displayed in 
several corners of the apartment. Added to that, Uttara the Icon shows on-screen texts like "with enchanting art" and "timeless art" to highlight how artistic and aesthetic elements are highly incorporated in its building. It makes the apartment look beautiful as a work of art by involving and being inspired by various artworks including traditional arts. A different strategy is applied by Barsa City's apartment. It does not use any traditional elements in aestheticizing its tall building. In line with its tagline "Urban Millenial Living", Barsa City attempts to render an urbanized modern lifestyle for the millennial generation without incorporating the considered traditional elements in its advertisement as well as promotional video.

Such an aestheticization of urban space is undoubtedly aimed to encourage people, particularly target consumer, to consume. It is actually similar to the logic of tourism, in which tourism spaces are constantly furnished and promoted to be consumed. In the under-studied advertisements and promotional videos, the promoted apartments are positioned as part of tourist attraction in Yogyakarta, which needs to be consumed and gazed at. In their promotional videos, it could be seen that the three apartments are targetted people from outside of Yogyakarta rather than from Yogyakarta. Those apartments attempt to attract prospective consumers, who need housing in Yogyakarta, either permanently or temporarily. Not surprisingly, in its advertisements and videos, those apartments attempt to show how attractive Yogyakarta is as a city to live, to study, and even to invest in. Uttara the Icon, for instance, represents what John Urry \& Jonas Larsen (2011) suggest as the "tourist gaze". Tourist gaze refers to ways of seeing in tourism discourse. Tourist, in this case, is positioned as the gazer or the subject of gaze, while tourism objects, which can be buildings, landscapes, places, foods, traditions and so on, are positioned as the gazees or objects of [tourist] gaze. This tourist gaze plays an important role in the production of tourist experience. According to Urry and Larsen, this gaze is not something neutral and as it is, but is constructed through signs and visual discourses to produce distinct pleasure for tourists. Uttara the Icon's video shows this inclination. Its target consumers are positioned as tourists, who come to Yogyakarta and need a new place to live. The position of these outsiders is emphasized through the visualization of occupants of Uttara the Icon, who are enjoying tourism spots in Yogyakarta such as by visiting traditional markets, historical buildings, enjoying traditional food, seeing the process of making batik, or meeting and interacting with people from Yogyakarta. Series of visual modes showing tourist activities are used conjointly with the on-screen texts "their kindness" (min. 00:01:06) or "their own taste" (min. 00:01:08). The word "their", in this regard, refers to Yogyakarta's inhabitants. It means the promotional video uses the viewpoint of the visitors/tourists, who come to Yogyakarta to experience "their" kindness, taste, lifestyle, or whatever it is. The visitors/tourists' position in the video is also revealed from the scenes, in which an occupant of Uttara the Icon is holding a camera to capture her tourist experiences (see Figure 5).

The camera itself is an instrument to freeze the tourist gaze, which brings distinct pleasure to the tourist, who in this video is the occupant of Uttara the Icon. In other words, Uttara the Icon does not only provide a modern and aesthetic place to live but also the distinct pleasure of experiencing the urban life of Yogyakarta.

\section{Spatial De-differentiation: Spectacle of One- Stop-Service}

In its advertisement, Barsa City offers mixeduse building consisting of apartment, shophouse

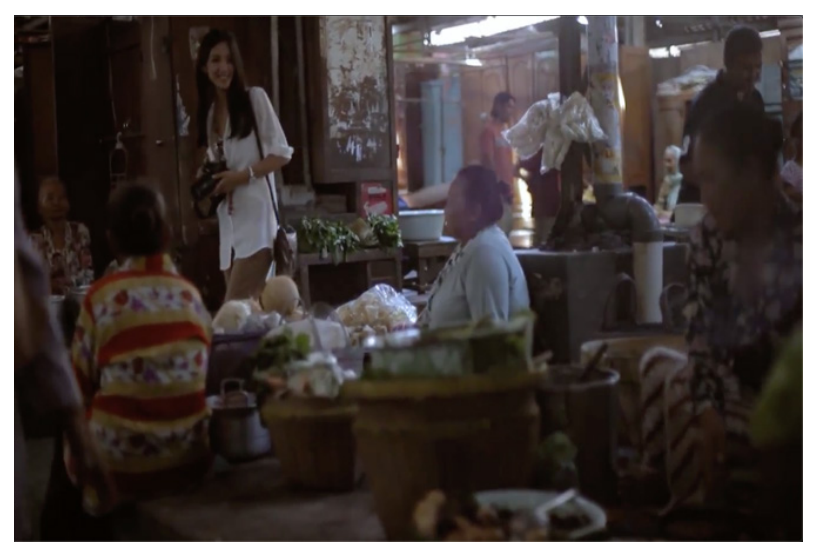

Figure 5. Uttara the Icon's occupant with a camera. Source: Uttara the Icons's Promotional Video (min. 00:00:58). https://www.youtube.com/watch?v=-pbpmdihz_o\&t=30s 
and shopping gallery. In its promotional video, it adds hotel and co-working space. All those buildings locate in one complex named Barsa City. Not only does the animation video show the series of buildings existing in the complex, but it gives snippet views of the buildings' interior. Both advertisement and promotional video of Barsa City use visual semiotic modes of groups of people doing activities outside and inside the buildings. It attempts to show that as a mixed-use complex, Barsa City provides one-stop-services for living, studying, working, and spending leisure time. The mixed-use complex, referring to George Ritzer's ideas, is a striking example of what socalled spatial implosion. Ritzer asserts that such a spatial implosion is part of re-enchanting the world of consumption. It produces a cityscape, in which different spatial entities are combined or merged, so those spaces become hard to distinguish. There is "a growing inability to differentiate among things and among places. They all are coming to interpenetrate, all imploding into one another " (Ritzer, 2010: 134). Ritzer continues, "these imploded worlds [spaces] represent a kind of spectacle that draws consumers into them and leads them to consume" (2010: 132). The imploded spaces, in other words, are purposefully created to encourage and ensure people to reach the maximum consumption. This spatial implosion brings people to a world that is increasingly characterized by dedifferentiation. In line with Ritzer's idea, it could be seen that Barsa City also offers interpenetrating spaces, where the boundaries between apartments, hotels, shopping galleries, and so on become blurred or even disappeared. A similar tendency of spatial implosion is also revealed in The Palace's advertisement and promotional video. The Palace does not sell a mixed-use complex like Barsa City. However, from the very beginning, The Palace underlines that their products are apartment and condotel (condominium hotel), which are placed in one location. In its advertisements, The Palace uses a tagline "The Best Choice for Investment, Living and Leisure" indicating that The Palace provides one-stop-services in one same location. The prospective tenants or owners could not only obtain a cozy place to live but also to invest and to spend leisure in the Palace. The video renders various in-house services provided equally by apartment and condotel of The Palace such as the room, restaurant, swimming pool, and green open area. On this point, spatial boundaries between apartment and condotel are, to some extent, blurred and even difficult to distinguish. Not only do both offer similar services, but they also share certain spaces and services for their tenants or owners. It causes such confusion, which services belong to the apartment and which belong to the condotel.

Different from Barsa City and The Palace, Uttara the Icon offers a slightly different strategy. Spatial de-differentiation is not palpably shown in its advertisement and promotional video. The Uttara the Icon's video focuses more on the detailed aesthetic elements of its apartment space. The apartment itself does not offer various services and spaces, which locate in one building like Barsa City and The Palace. However, there is one scene, which indicates that the apartment also functions as a lifestyle center, other than for living. It is underlined by the use of on-screen text "a lifestyle hub" (min. 00:03:11) and visual modes of space wherein a bunch of people gathers and do activities. Such visual modes are visible as well in Barsa City's and The Palace's advertisements and videos. Since Uttara the Icon mentions explicitly the word "lifestyle" in its video, it is obvious that the apartment is also aimed as the center of lifestyle. It needs to underline that the apartment is not only a good place for living but for meeting people, spending leisure, and experiencing an urban lifestyle. Concerning lifestyle, Stephen Graham (2016: 757) asserts that apartment buildings with high building designs are often used as tools to symbolize the power and economic stability of both the developer and the owner/the tenant. Economic stability is mostly expressed through the ability to consume and choose certain lifestyles. It is not surprising that apartments are mostly intertwined with the discourse of lifestyle and consumerism. The economic stability of the apartment's owners or tenants is manifested through various activities facilitated by the apartment. On this point, the apartment itself tends to position itself as a onestop-service building. Concerning Uttara the Icon, 
its apartment is also considered as a one-stop service building, imploding the living space and lifestyle space. A similar spatial de-differentiation is also seen from the implosion of production and consumption spaces in the context of Barsa City. As stated in its advertisement, Barsa City offers some services locating in one mixed-use complex, which blurs or even removes spatial boundaries between space for production and space for consumption. The space for productive work is not separated from the space for leisure and consumption. The space for studying, for living, and investment are also imploded into one same space as underlined in Barsa City and The Palace advertisements. As seen in the under-studied advertisements and promotional videos, those apartments equally involve the notion of Yogyakarta as a student city. Although the three of them do not specifically position themselves as student apartments, they visibly incorporate the element of studying in their advertisements and promotional videos. In its advertisement, Barsa City mentions education among other services offered to its consumers. It is related to the strategic location of Barsa City, which is not far from several big campuses in the eastern side of Yogyakarta like the Catholic University of Atma Jaya Yogyakarta or the University of National Development "Veteran" Yogyakarta.

The Palace uses the tagline "The Best Choice for investment, living and leisure" in its advertisement indicating the implosion of space for investment, for living, and leisure. It does not overtly mention the space for studying; however, The Palace applies spatial compression by cutting the distance between The Palace and four campuses in Yogyakarta, namely, UGM, UII, University of Sanata Dharma, and Catholic University of Atma Jaya Yogyakarta. It attempts to underline that those four campuses are nearby The Palace and could be reached in only a couple of minutes. Uttara the Icon uses the same strategy in its video. Using animation techniques, Uttara the Icon cuts the spatial distance between UGM and its location. This spatial compression is also underlined by using on-screen text "Urban Lifestyle within walking distance to world-class university". The on-screen text appears conjointly with the visual mode of the central building of UGM. The phrase "within walking distance" is an expression to show the close distance between Uttara the Icon and UGM. The word "Urban Lifestyle" in the on-screen text refers to the apartment, highlighting its position as the lifestyle hub. Studying and experiencing urban lifestyle, on this point, are imploded and conjoined. This fact explains Guy Debord's (1967/2002) theses of "humanism of commodity". By this theses, Debord argues that once the workers finish their working time, they do not actually free and could escape from capitalist exploitation. Conversely, once they finish their works and leave the realm of production, they are immediately greeted and welcomed to the realm of consumption. In this regard, they are treated with humanity and dignity to get them to consume commodities willingly and happily. It could not be easier if the spatial distance from the realm of production to the realm of consumption is compressed. This is what Debord suggests as the constant presence of the spectacle. In more detail, he asserts, "the spectacle is both the result and the goal of the dominant mode of production" (1967/2002, Theses 6) it always exists both in the realm of production and of consumption as the ultimate goal of the ruling economic order. Based on Debord's idea, it could be seen that in the context of Barsa City, The Palace, and Uttara the Icon, the spectacle even exists in the most private realm known as home, wherein the spatial boundaries between consumption space, leisure space, and working/studying space are now twisted and imploded.

\section{Selling the Spectacular Time}

In the society of the spectacle, as Debord asserts, we are confronted by what so-called pseudocyclical time, that is, the required time to produce commodities and, concomitantly, the consumable time which is commodified $((1967 / 2002$, Theses 149). Pseudocyclical time, according to Debord, recombines as well as integrates everything that was previously separated in everyday life. In the past, there was a clear division of time such as time for work, for personal affairs, for studying, time for leisure, and so on. In the society of the spectacle, 
time unifies all those separate things and functions to enhance desires for consumption. For this reason, blocks of time are managed and transformed by the capitalist mode of production. Blocks of time are designed to be "fully equipped", underpinned by a variety of facilities and packaged as "everything is included". When everything is included in the blocks of time, the use of time can be controlled and directed to access the abundance of commodities. In the context of under-studied advertisements and promotional videos, the idiom of "everything is included" becomes visually prominent. Putting various services and various activities together in one place is the effort to realized "everything is included". When "everything is included", blocks of time for working, for shopping, for studying, for leisure, and so on could be managed and compressed. As a result, everything could be done in speed. The usage of time in those imploded spaces could be controlled and directed to actively foster consumption. Not surprisingly, those apartments mostly underline the abundance of time for the owners/tenants to participate actively in the new means of consumption provided, either by the apartment itself or other facilities in the vicinity.

"Everything is included", which involves spatial de-differentiation, as earlier mentioned, have obviously resulted in the time implosion. When the spatial distance is removed or eliminated, the consumable time to reach a space becomes shortened. This fact is emphasized by Ritzer (Ritzer, 2010) by suggesting that one of the goals of a capitalist economy is to ensure that everyone can consume all the time, every hour, every day, every year. Because everything is included, and everything is spectacularized, what happens is the spectacular use of time. The spectacle that is offered makes us drown and sometimes it can get lost in time (Ritzer, 2010: 159). Related to that, in their promotional video, the three apartments depict images of cars moving in the vicinity. The existence of means of transportation in urban space is basically related to the notion of time-space compression, which characterizes urban life. Consuming time in urban space is designed to be more flexible or, if possible, becomes unlimited. It is obvious, on this point, that providing a wide array of commodities in one location has two paradoxical implications. On the one hand, it allows a time-compression due to the cutting or eliminating distances, but at the same time, it also allows people to spend much longer time for consumption. This temporal paradox, compressing and prolonging the time, is prominently promoted in the under-studied advertisements and promotional videos. In Barsa City's advertisement, for example, both time compression and time prolong are palpable. On the one hand, Barsa City underlines the timecompression and even promises the efficiency of time by living in the mixed-use complex. It overtly states "the concept of the mixed-use building offers time efficiency". The time efficiency is achieved by merging and combining various services in one complex. It means inhabitants of the mixeduse complex do not need to spend hours in the street to move from one facility to another. They are kept in one location and, therefore, they save and have an abundance of time to spend within the location. Barsa City even emphasizes the fact that urban area is mostly crowded and congested, which causes inefficiency of time. On this point, Barsa City implies that by living in the mixed-use complex, inhabitants could have prolonged time to spend within the complex with full of new means of consumption.

The Palace, similarly, displays a list of time duration to reach a certain destination from and to the apartment such as from the airport, to campuses, to hospital, and so on. Time compression and speed reveal to be part of the commodities that The Palace sells in its advertisements. It uses the words "close to anywhere", indicating that it has a strategic location, which enables its inhabitants to reach any important location within minutes. It even displays a certain obvious time duration to reach a certain location from and to The Palace. For example, it mentions that it only needs 10 minutes to get to UGM and UII. Added to that, the word "close to" appears prominently in the advertisement. The word "close to", indeed, does not directly refer to the temporal aspect; however, such a word is used to indicate the consumable time in reaching a certain destination. The basic logic of mentioning the exact time duration and the word 
"close to" is speed. In this regard, speed becomes a significant clue to be sold and consumed. The three apartments equally offer time-compression and speed as part of the solution to living in the urban area. But at the same time, they also promote prolonged and extended time to participate in the consumption and urban lifestyle.

\section{Conclusion}

The growing development projects of apartment in Yogyakarta has changed the face of Yogyakarta, which has been known as a cultural and student city. The High-rise building of apartment plays a significant role in structuring the urban space and life of Yogyakarta in the last decade. The close examination to the advertisement and promotional video of Barsa City, The Palace, and Uttara the Icon reveals that the apartment is considered a marker of modernity and urban life. By examing multimodal ensemble used in the advertisements and promotional videos, this article shows that apartments are functionalized to create a spectacle of the city. In this regard, urban space and life are aestheticized and spectacularized by the high-rise building of apartment. At the same time, the apartment itself is also aestheticized and displayed as part of dramatic and extravagant urban arts. Apartments are presented not merely as spaces for living but also as one-stopservice buildings especially for consumption and experiencing urban lifestyles. In accordance with that, spatial de-differentiation discursively emerges in advertisements and promotional videos of the three apartments. Spatial differences and boundaries are merged and eliminated because everything is included and located in one place or building or location. Spatial boundaries become difficult to distinguish because different spaces are imploded and transformed into one-stop-spaces. Furthermore, spatial implosion is also conjoined with time implosion. Advertisements and promotional videos of the apartment in Yogyakarta promote temporal paradox. On the one hand, those advertised apartments promote time-compression and speed as basic logic of life in urban space, but on the other hand, it also promotes prolonged and extended time to foster consumption and actively involve in the urban lifestyles.

\section{References}

Ali, M. M., \& Al-Kodmany, K. (2012). Tall Buildings and Urban Habitat of 21st Century: A Global Perspective. Buildings, Vol. 2, 384423.

Askia, F. (2018). Apartemen di Yogya Laris Manis. Rumah.Com. Retrieved October 5, 2020 from https://www.rumah.com/berita-properti/ 2018/9/174596/apartemen-di-yogya-larismanis

Barsa City. (2017). Barsa City. Retrieved October 5, 2020 from https://www.youtube.com/ watch? $v=r P i 9 H m A P L N g \& t=2 s$

Barsa City. (2019). Barsa City. Retrieved October 5, 2020 from https://www.youtube.com/ watch? $v=r P i 9 H m A P L N g \& t=2 s$

kabarbisnis.com. (2017). Ciputra Bangun Mixed Used Apartment di Yogyakarta Mulai Rp 400 jutaan. Retrieved October 10, 2020 from https://kabarbisnis.com/read/2880054/ ciputra-bangun-mixed-used-apartment-diyogyakarta-mulai-rp400-jutaan

Cronin, A. M. (2010). Advertising, Commercial Spaces and the Urban. Palgrave Macmillan.

Debord, G. (1967/2002). The Society of the Spectacle. Hobgoblin Press.

Devi, Octasya Yusnindita \& Pradoto, W. (2017). Keberadaan Apartemen dan Pengaruhnya Terhadap Aktivitas Sosial dan EKonomi Kawasan Seturan, Yogyakarta. Teknik PWK (Perencanaan Wilayah Kota), Vol.6(No.2), 86-97.

Featherstone, M. (2007). Consumer Culture and Postmodernism (2nd ed.). SAGE Publications Ltd.

Gottman, J. (1966). Why the Skycraper? Geographical Review, Vol.56 (No.2), 190-212.

Graham, S. (2016). Vanity and Violence: On the Politics of Skycrapers. City, Vol. 20 (No.5), 755-771.

Indonesia, B. (2019). Kajian Ekonomi dan Keuangan Regional Daerah Istimewa Yogyakarta: DIY Membangun, Kinerja Ekonomi Melesat. Bank 
Indonesia.

jogja.tribunnews.com. (2018). Barsa City Siap Membangun Sayap Selatan Cornell Apartment. Jogja Tribun News. Retrieved October 8, 2020 from https://jogja.tribunnews. com/2018/02/22/barsa-city-siap-bangunsayap-selatan-cornell-apartment

Kusrini. (2016). Fotografi Jalanan: Membingkai Kota dalam Cerita. Journal of Urban Society's Art, Vol. 3(No.2), 102-109.

Miles, S. (2010). Space for Consumption: Pleasure and Placelessness in the Post-Industrial City. SAGE Publications Ltd.

Noviani, R. (2018). Wacana Multimodal Menurut Gunter Kress dan Theo van Leeuwen. In Hamparan Wacana: Dari Praktik Ideologi, Media, hingga Kritik Poskolonial (pp. 107134). Ombak.

radarjogja.jawapos.com. (2019). Tahun Ini, Lima Apartemen DIbangun. Retrieved October 5, 2020 from https://radarjogja.jawapos. com/2019/01/09/tahun-ini-lima-apartemendibangun
Ritzer, G. (2010). Enchanting a Disenchanted World: Continuity and Change in the Cathedrals of Consumption (3rd ed.). SAGE Publications Ltd.

the Pallace. (2019). The Palace. Retrieved October 5, 2020 from https://www.youtube.com/ watch?v=HLa9s_pcC-w [accessed 5 October 2020

Thia, B. (2014). Pemetaan Persepsi Mahasiswa pada Positioning Apartemen di Yogyakarta.

Urry, John \&Larsern, J. (2011). The Tourist Gaze 3.0. SAGE Publications Ltd.

uttaratheicon.co.id. (2014). Uttara the Icon. Retrieved October 5, 2020 from https://www. youtube.com/watch?v=-pbpmdihz_o

uttaratheicon.co.id. (2017). Property Developer “Consumer Choice Awards. "Retrieved October 10, 2020 from https://www.uttaratheicon. co.id/news_076.html

Wicaksono, Singgih Prio \& Juwariyah, A. (2019). The Visual Language of Consumerism in Contemporary Artworks. Journal of Urban Society's Arts, Vol.6(No.1), 56-62. 